\title{
Implementation of biosafety in infection control: a 10-year review
}

\author{
*Uwandu, M. O., Ige, F. A., Okwuraiwe, A. P., Onwuamah, C. K., and Audu, R. A. \\ Centre for Human Virology and Genomics, Nigeria Institute of Medical Research, Yaba, Lagos, Nigeria \\ *Correspondence to: uwandumabel@yahoo.com; +2348033467717
}

\begin{abstract}
:
Biosafety is an important issue globally, as a line of defence that protects health personnel, public and the environment from exposure to hazardous agents. Most developing nations have weak health systems and consequently weak biosafety. Engaging in an external quality program such as an accreditation process will help build capacity and competence in all areas. The Centre for Human Virology and Genomics (CHVG) laboratory of the Nigerian Institute of Medical Research, Lagos, Nigeria started its biosafety program in compliance to international standards stipulated by ISO 15189:2012, in its journey towards laboratory accreditation. Accreditation is widely used to attest for laboratory competence. In the quest for laboratory accreditation, several processes were implemented to ensure compliance, one of which was biosafety. Simple remedial actions and policies that have worked in other climes were applied over a 10-year period in the CHVG laboratory. A significant drop in nonconforming incidences and laboratory accidents was seen while biosafety audits showed improvement in safety practices.
\end{abstract}

Keywords: Biosafety, Infection control, audit

Copyright 2021 AJCEM Open Access. This article is licensed and distributed under the terms of the Creative Commons Attrition 4.0 International License $<$ a rel="license" href="http://creativecommons.org/licenses/by/4.0/", which permits unrestricted use, distribution and reproduction in any medium, provided credit is given to the original author(s) and the source. Editor-in-Chief: Prof. S. S. Taiwo

\section{Mise en œuvre de la biosécurité dans la lutte contre les infections: un examen décennal}

\author{
*Uwandu, M. O., Ige, F. A., Okwuraiwe, A. P., Onwuamah, C. K., et Audu, R. A.
}

Centre de virologie humaine et de génomique, Institut nigérian de recherche médicale, Yaba, Lagos, Nigéria *Correspondance à: uwandumabel@yahoo.com; +2348033467717

\begin{abstract}
Abstrait:
La biosécurité est une question importante à l'échelle mondiale, en tant que ligne de défense qui protège le personnel de santé, le public et l'environnement de l'exposition à des agents dangereux. La plupart des pays en développement ont des systèmes de santé faibles et, par conséquent, une faible sécurité biologique. S'engager dans un programme de qualité externe tel qu'un processus d'accréditation aidera à renforcer les capacités et les compétences dans tous les domaines. Le laboratoire du Centre de virologie humaine et de génomique (CHVG) de I'Institut nigérian de recherche médicale de Lagos, au Nigéria, a commencé son programme de biosécurité conformément aux normes internationales stipulées par ISO 15189: 2012, dans son parcours vers l'accréditation des laboratoires. L'accréditation est largement utilisée pour attester la compétence du laboratoire. Dans la recherche de l'accréditation des laboratoires, plusieurs processus ont été mis en œuvre pour assurer la conformité, dont l'un était la biosécurité. Des mesures correctives simples et des politiques qui ont fonctionné sous d'autres climats ont été appliquées sur une période de 10 ans dans le laboratoire du CHVG. Une baisse significative des incidents non conformes et des accidents de laboratoire a été observée tandis que les audits de biosécurité ont montré une amélioration des pratiques de sécurité.
\end{abstract}


Mots clés: Biosécurité, Contrôle des infections, audit

\section{Introduction:}

Accreditation is an authorized recognition of competency issued by a third party often following the results of a conformity assessment (1). It shows capabilities and proficiency in a specific field; for the laboratory, it is a certification of competency to perform specific tests, classes or types of tests mostly in conformity to international standards such as the International Organization for Standardization (ISO) and the International Electrotechnical Commission (IEC) $(1,2)$.

Accreditation is an essential element by which implementing organizations can improve managerial and technical capability such as laboratory safety while achieving international best practices (1). The accreditation process must show full compliance with specific laws, regulations, standards, protocols, and agreements, this helps strengthens processes and technical expertise of participating bodies (2). In the journey towards achieving accreditation, the Centre for Human Virology and Genomics (CHVG), was introduced to Quality Management System (QMS) and Strengthening Laboratory Management Toward Accreditation (SLMTA) programmes. SLMTA is an initiative of the World Health Organization (WHO), a framework tool for public health-based laboratories to achieve ISO 15189 standards and prepare such laboratories for accreditation (3). Through the establishment of standardised processes, SLMTA measures and evaluates the progress of laboratory systems towards international accreditation via the Stepwise Laboratory Improvement Process Towards Accreditation (SLIPTA) checklist tool. The SLIPTA checklist is a framework of auditing tool that allows laboratories measure and evaluate the progress of its laboratory quality system. SLIPTA checklist is used to evaluate biosafety for conformity to ISO standards (3).

Biosafety is the safe handling and containment of infectious microorganisms and hazardous biological materials (4). It is an important issue in laboratory settings worldwide, especially in developing countries where standardized practices are lacking (5). It is a critical tool in the global fight against infectious diseases spread particularly in the face of highly contagious diseases of recent times such as Ebola and Lassa viruses (6-8). Most laboratory infections have been reported to occur as a result of inattention to safety practices, error, accident or carelessness in handling infectious agents $(5,8)$. Hence labora- tories are required to provide means to control infections and monitor these measures to ensure conformity to best practise and reduce laboratory accidents (8). This manuscript presents a 10 year (2006-2016) retrospective review of biosafety indicators, monitored in CHVG in the laboratory's pathway to accreditation to ISO 15189:2012 in 2017.

\section{Methodology:}

The CHVG created the biosafety process in 2006 as part of the quality essential processes required to achieve accreditation. Its biosafety program commenced with the training and appointment of a dedicated biosafety officer to implement and report on safety issues monthly. A biosafety manual to direct process activities was developed, which had references to the WHO safety regulations for a biosafety level 2 laboratories and also the local regulatory agency laws such as the Federal Environmental Protection Agency (FEPA) waste management laws.

Biosafety working documents which included standard operating procedures (SOPs) and job aids to address various safety areas such as waste management, fire emergency, microorganism transfer or transport, access control, sample spill checks, laboratory accidents (needle pricks and sample splash) and personal protective equipment (PPE) use were developed. Fire emergency trainings and drills were regularly conducted; spill and microorganism transfer and handling trainings were followed through. On-site training of all personnel on the use of these relevant documents and activities were done.

Key indicators for monitoring biosafety were identified and monitored monthly for compliance. Monitoring of noncompliance to policies and procedures were tracked and corrective actions were analysed for effectiveness, subsequent training from gaps identified were also initiated. Periodic safety audits were conducted to measure the effectiveness and implementation. Indicators of effective QMS such as rate of laboratory accidents and nonconformities were tracked to maintain the integrity of the quality of laboratory biosafety. All indicators were monitored in reviews and analysed annually to detect issues, trends and lessons for improvement.

Two key indicators were reviewed; laboratory accidents report and internal safety audit reports. Safety audits were conducted using section twelve of the standard SLIPTA 
checklist to monitor biosafety implementation and effectiveness. Laboratory accidents were promptly managed using an established Post Exposure Prophylaxis (PEP) policy. This involved screening for a baseline HIV test and with a negative result obtained, prescription of antiretroviral drugs for a 28 -day dosage period.

\section{Results:}

\section{Key biosafety indicators}

The results of the key biosafety indicators monitored in the 10 -year period is displayed in Fig 1 . During the 10 years under review, there were 15 laboratory accidents (12 needle pricks and 3 sample splashes on mucous membrane) in CHVG. The highest frequency of accidents occurred between 2008 and 2011. There was no sero-conversion after 3 months post exposure surveillance.

Scores of biosafety audit assessment results over four years

Fig 2 represents the aggregate scores of the biosafety process monitored in preparation for laboratory accreditation. From 2010 to 2013, the CHVG was audited using SLIPTA checklist on biosafety. The percentages for biosafety over this period were $92.5 \%$, 95\%, $93 \%, 97.6 \%$ in 2010, 2011, 2012 and 2013 respectively.

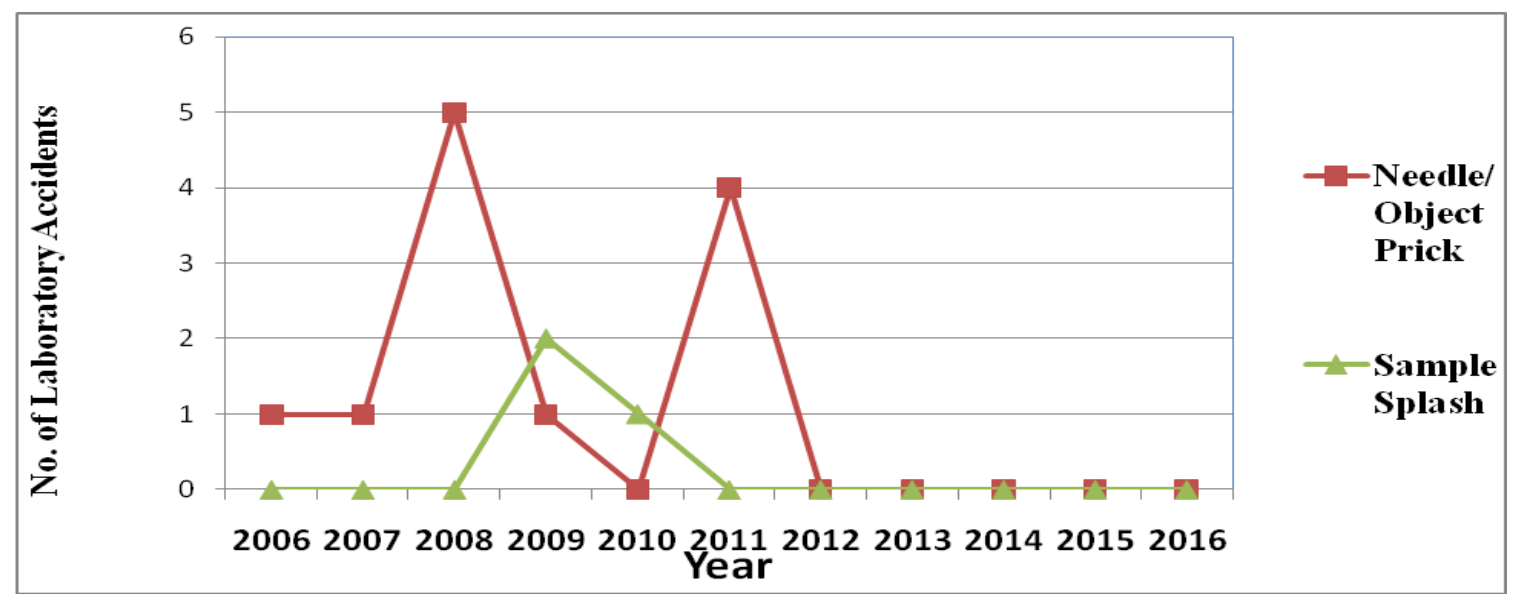

Fig 1: Needle prick and sample splash laboratory accidents in CHVG, NIMR, Lagos, Nigeria

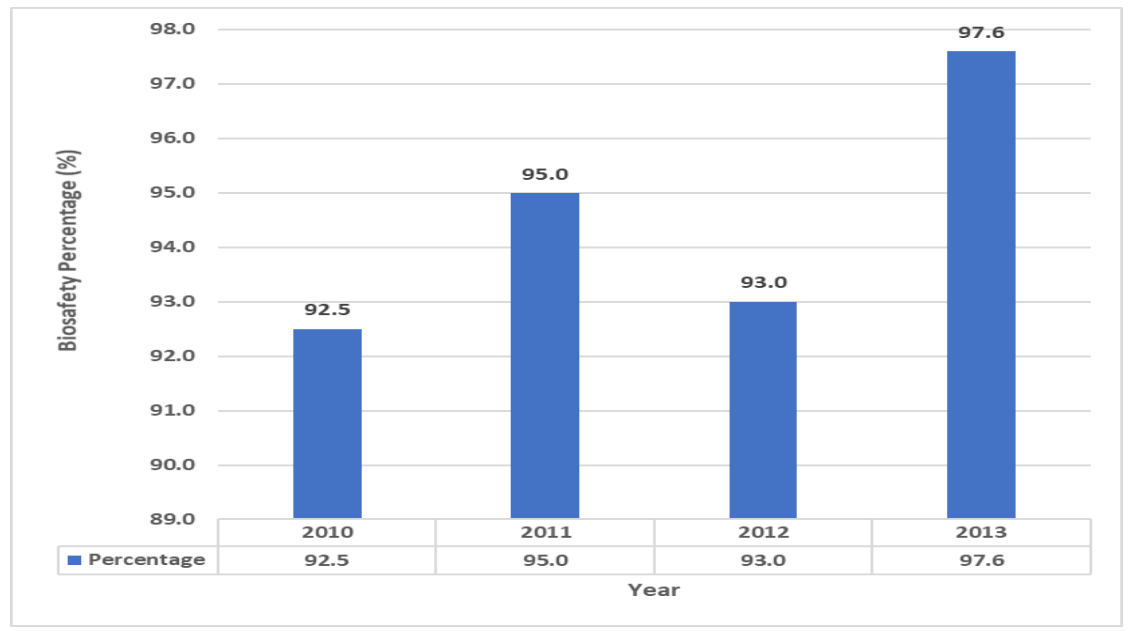

Fig 2: Audit scores from 2010 to 2013 using the SLIPTA checklist on biosafety in CHVG, NIMR, Lagos, Nigeria 


\section{Discussion:}

Fifteen occurrences of laboratory accidents (12 needle pricks and 3 sample splashes) were reported during this period. The highest incidences $(n=6)$ were observed in 2008 and 2009. Preventive policies to counter this were established and that helped achieve reduction in laboratory accidents. The laboratory was erstwhile utilizing syringes and needles for phlebotomy, which was abolished and a policy of "no recap of needle" was introduced in 2011. Training on the no-recap policy was done and use of needles was abolished and replaced by vacutainer use, which is a closed system of blood collection. The use of vacutainer helped stop needle pricks and was effective as a control measure as no further accidents were reported after 2011.

The World Health Organization (WHO) recommends the use of closed systems for blood collection in phlebotomy as they have proven to be safer than open systems such as syringe and needle (9). Various studies have shown that recapping of needles is a major cause of needle pricks while the use of vacutainer for venepuncture help reduce the risk of direct exposure to blood, prevent needle pricks and are safer. This was also found in our practice as the rate of laboratory accidents due to needle pricks reduced and became nonexistent in subsequent years $(10,11)$. Vacutainer use also assisted in improving customer satisfaction as collection of multiple samples from a single venepuncture was an advantage in the system. The use of PEP is widely accepted and proven to be effective in occupational exposure to HIV prevention, as reported in many other studies (12).

The results of the biosafety audits were used as key indicators and were monitored for 4 years. A resultant average score of $95 \%$ was achieved during this period. This improvement was as seen in other studies that ascribed improvement to participating in improvement steps and processes toward accreditation (2). Initiation of these audits and monitoring of other key indicators such as fire emergencies and drills, sample spill checks and drills, waste disposal monitoring and PEP usage, helped the successful implementation of biosafety as a laboratory culture. The implementation of QMS and a dedicated safety officer with regular biosafety audits were instrumental in institu- tionalizing and sustaining the biosafety process in CHVG.

\section{Conclusion:}

The key factors that helped the implementation of biosafety standards were training, resources allocation and monitoring for continual improvement. Laboratory accreditation makes training, resource allocation, monitoring and institutionalization of quality processes available and these are essential elements for implementation and sustenance of an effective biosafety program. Enrolling laboratories for accreditation allow development of competence thereby strengthening the weak health systems in developing countries. Ultimately, this helps in the global fight against infectious diseases particularly the re-emerging highly contagious diseases of our times.

\section{References:}

1. Zhai, P., Wang, R., Hu, D., Li, J., and Zhou, Y. Enhancing the capabilities of biosafety laboratories through the established accreditation system: Development of the biosafety laboratory accreditation system in China. Journal of Biosafety and Biosecurity. 2019; 1: 86-89.

2. Peter, T. F., Rotz, P. D., Blair, D. H., Khine, A., Freeman, R. R., and Murtagh, M. M. Impact of Laboratory Accreditation on Patient Care and the Health System. Am J Clin Pathol. 2010; 134 (4): 550-555

3. Yao, K., Maruta, T., Luman, E. T., and Nkengasong, J. N. The SLMTA programme: Transforming the laboratory landscape in developing countries. Afr J Lab Med. 2014; 3 (3): 194. doi:10.4102/ajlm.v3i2.194

4. World Health Organization. Laboratory Biosafety Manual. Containment of Biohazards - Methods Laboratories - Standards Laboratory Infection Prevention and Control. $3^{\text {rd }}$ ed. 2004

5. Nasim, S., Shahid, A., Muhammad, M., Kazim, S., and Siddiqui, T. Practices and awareness regarding biosafety measures among laboratory technicians working in clinical laboratories in Karachi, Pakistan. Applied Biosafety. 2010; 15 (4): 172-179.

6. Salu, O. B., James, A. B., Oke, B. O., et al. Biosafety level-2 laboratory diagnosis of Zaire Ebola virus disease imported from Liberia to Nigeria. Afr J Lab Med. 2016; 5 (1): a468. http://dx.doi.org/10.4102/ajlm.v5i1.468

7. Maxmen, A. Deadly Lassa fever outbreak threatens Nigeria revamped health agency. Nature. 2018; 555: 421-422. www.nature.com/artticles/d41586-018-0317-y.

8. Bishop, A. A. Investigation of Biological, Sociological, and Statistical Factors Contributing to the Emergence and Spread of the 2014 Ebola Virus Disease Outbreak in West Africa. Honors Theses. 2016; Paper 832. https://diqitalcommons.colby.edu/honorstheses/832

9. World Health Organization Guidelines on Drawing Blood: Best Practices in Phlebotomy. Geneva: WHO, 2010 https://www.ncbi.nlm.nih.gov/books/NBK138650/

10. Lippi, G., Salvagno G. L., Montagnana, M., Franchini M., and Guidi, G. C. Phlebotomy issues and quality improvement in results of laboratory testing. Clin Lab. 2006; 52: 217-230.

11. Adefolalu, A. Needle stick injuries and health workers: a preventable menace. Ann Med HIth Sci Res. 2014; 4 (Suppl 2):S159-S160.doi:10.4103/2141-9248.138046

12. Hamlyn, E., and Easterbrook, P. Occupational exposure to HIV and the use of post-exposure prophylaxis. Occupational Medicine. 2007; 57 (5): 329-336 